WISSENSCHAFTSZENTRUM BERLIN FÜR SOZIALFORSCHUNG

SOCIAL SCIENCE RESEARCH

\author{
Benny Geys * \\ Bruno Heyndels **
}

\title{
Disentangling the Effects of Political Fragmentation on Voter Turnout: the Flemish Municipal Elections
}

* WZB

** Vrije Universiteit Brussel

SP || $2006-07$

June 2006

ISSN Nr. $0722-6748$

Research Area Markets and Politics

Research Unit Market Processes and Governance
Schwerpunkt

Märkte und Politik

Abteilung

Marktprozesse und Steuerung 
Zitierweise/Citation:

Benny Geys and Bruno Heyndels, Disentangling the Effects of Political Fragmentation on Voter Turnout: the Flemish Municipal Elections, Discussion Paper

SP II 2006 - 07, Wissenschaftszentrum Berlin, 2006.

Wissenschaftszentrum Berlin für Sozialforschung gGmbH,

Reichpietschufer 50, 10785 Berlin, Germany, Tel. (030) 25491 - 0

Internet: www.wz-berlin.de 


\section{ABSTRACT \\ Disentangling the Effects of Political Fragmentation on Voter Turnout: the Flemish Municipal Elections}

by Benny Geys and Bruno Heyndels *

Political fragmentation has been shown to be an important determinant of electoral turnout. We introduce an empirical approach that allows disentangling the impact of two dimensions of such fragmentation: the number of parties and the size inequalities between those parties. This is important as it allows us to assess the size, significance and direction of the individual effects of each element - an aspect disregarded in previous research. Our empirical analysis of the 2000 Flemish municipal elections shows that a higher number of parties competing in the election lowers turnout. The size-inequalities between the parties exert a positive - though insignificant - influence on voter participation.

Keywords: Voter turnout, political fragmentation, local elections

JEL Classification: D72, H7O

ZUSAMMENFASSUNG

\section{Auswirkungen politischer Zersplitterung auf die Wahlbeteiligung: die flämischen Kommunalwahlen}

Es hat sich gezeigt, dass politische Zersplitterung ein wichtiger Faktor für die Wahlbeteiligung ist. Wir stellen einen empirischen Ansatz vor, der den Einfluss von zwei unterschiedlichen Dimensionen der Zersplitterung herausarbeitet, nämlich die Anzahl der Parteien und die Größenunterschiede zwischen diesen Parteien. Dies ermöglicht, Größe, Bedeutung und Richtung der individuellen Einflüsse eines jeden Elements zu beurteilen, was in der Forschung bisher vernachlässigt worden ist. Unsere empirische Analyse der flämischen Kommunalwahlen im Jahr 2000 zeigt: je mehr Parteien zur Wahl antreten, desto geringer ist die Wahlbeteiligung. Die Größenunterschiede zwischen den Parteien haben einen positiven, wenn auch nicht signifikanten Einfluss auf die Wahlbeteiligung.

* We thank John Ashworth, Matthias Benz, An Buysschaert, Bruno De Borger, Kris Deschouwer, Marc Hooghe, Wim Moesen, Per Tovmo, Ilse Verschueren, Kristien Werck and participants to the Annual Meetings of the European Public Choice Society in Belgirate (Italy) and the Midwest Political Science Association in Chicago (US) for their comments on previous versions of this paper. 


\section{Introduction}

Political systems based on proportional representation (PR) typically lead to a fragmented political landscape with higher numbers of parties in the election compared to plurality and majoritarian two-round systems (Duverger, 1972; Taagepera and Shugart, 1989 and Lijphart, 1994). Such party system fragmentation has been shown to affect voter participation in the political process. More precisely, two distinct dimensions of political fragmentation have been identified as potential determinants of electoral turnout: (a) the number of parties that participate in the elections and (b) the size inequalities between those parties. Still, in empirical work it has been common practice to either disregard one of the dimensions (looking only at the number of parties) or to treat both dimensions simultaneously in one index. Separation of the effects of both these dimensions is important for both statistical and empirical reasons. Statistically, ignoring one of both dimensions may lead to misspecification of the model if both dimensions matter and, consequently, to biased estimation results. Empirically, disentangling the effects is the only way to assess whether and to what extent each of the dimensions is relevant. This allows for a direct test of alternative hypotheses that have been introduced in the literature on electoral turnout and that have, as yet, remained untested. The central aim of the present paper therefore is to introduce an empirical approach that allows separating the effects of both dimensions of political fragmentation. Disentangling the fragmentation index into its constituent parts is indispensable to do so.

Our empirical work explains electoral turnout at the 2000 Flemish municipal elections. Despite the formal existence of mandatory voting, turnout rates vary considerably between municipalities allowing for an empirical analysis aimed at identifying the determinants of turnout (De Winter et al., 1991; Ackaert et al., 1992) and, more specifically, to investigate the 
role of political fragmentation. Assessing the effects of political fragmentation on turnout in a context of PR implies that we analyse the impact of a major characteristic of politics in many democratic countries that has until now received scant attention. Indeed, the turnout literature has focused strongly on plurality systems, which are essentially two-party systems. Actually, to the best of our knowledge, there is only one study that investigates the effect of fragmentation on turnout explicitly in a context of PR (Hansen, 1994). Still, as Hansen (1994) analyses turnout at Norwegian municipal elections, our own analysis is the first we know of that analyses fragmentation in a PR parliamentary context where the executive board is formed by a political majority, rather than being proportionate to the seats in the council (as in Norway).

The paper is structured as follows. In section 1 we provide the general theoretical framework for the analysis of electoral turnout. Section 2 surveys the literature on the relation between turnout and political fragmentation. The empirical analysis is discussed in section 3. The main findings indicate that the effects of both constituent elements of fragmentation - the number of parties and the size-inequalities - run in opposite direction. Turnout falls with the number of parties but rises the more unequal in size the political parties are. The latter effect, however, only approaches statistical significance at the $10 \%$ level. Finally, section 4 presents a summary of the main conclusions.

\section{General framework: voting in a multi-party context}

Almost 50 years ago, Downs (1957) laid out the groundwork for the expected utility model of voter turnout. This model argues that the individual voter is an homo oeconomicus, a rational 
man or woman who assesses the relative size of the costs and benefits of his/her possible actions. In deciding whether to vote or abstain, each voter calculates the expected utility from each possible action and votes only if the benefits of doing so outweigh the costs. Downs' (1957) model is - like later extensions to it - exclusively aimed at two candidate plurality elections. Hence, it does not take into account the effects from coalition formations that frequently arise in non-plurality multi-candidate elections. Extending the model to include such elections, it can be shown that a given individual will vote only if the net benefits of voting are strictly positive, i.e. if:

$$
\mathrm{R}=\left[\sum_{i=1}^{N-1}\left(p_{i}^{V}-p_{i}^{A}\right)\left(U_{i}-U_{N}\right)\right]-\mathrm{C}+\mathrm{D}>0
$$

$$
\begin{aligned}
& \mathrm{R}: \text { Net satisfaction, in utiles, an individual receives from voting } \\
& \mathrm{N}: \text { Number of possible outcomes (winning parties/coalitions) } \\
& p_{i}^{V}: \text { Probability that party/coalition i wins if you vote } \\
& p_{i}^{A}: \text { Probability that party/coalition i wins if you abstain } \\
& \mathrm{U}_{\mathrm{i}}: \text { Utility from the victory of party/coalition } \mathrm{i} \\
& \mathrm{C}: \text { Costs of voting } \\
& \mathrm{D}: \text { Expressive Benefits of voting }
\end{aligned}
$$

The net benefit from voting $(\mathrm{R})$ equals the sum of N-1 "instrumental" benefit terms, minus the costs of voting, plus the "expressive" or "consumption" benefits of voting (see also McKelvey and Ordeshook, 1972). Let us now take a closer look at each of these three elements. 
- The "instrumental" benefits for each individual voter depend on the future public policy that (s)he expects. This policy is assumed to depend solely on the party or coalition that wins the election. "Winning the election" here means that the party or coalition comes into power. Depending on the electoral context, "winning" may mean that the party obtains most votes or that it is successful in the coalition formation process. Formally, the formation of a political majority (government) may be seen as a two-stage process. First seats are allocated by voters and afterwards - in the second stage - a political majority forms as the outcome of coalition negotiations. The second stage of this process may be "empty" if voters in the first stage provide a single party with a fraction of the votes sufficiently large to secure a parliamentary majority. ${ }^{1}$ As can be clearly seen in expression (1), the instrumental benefit term is the product of two components. The first factor gives the probability that one's vote is decisive, meaning that it leads party/coalition i to victory. This probability of being decisive is given by the difference between the probability that party/coalition $i$ wins if one votes $\left(p_{i}^{V}\right)$ and the same probability when one abstains $\left(p_{i}^{A}\right)$. Implicit in this modelling is that voters may have an (indirect) influence on the coalition formation process. This will be the case if the votes (seats) obtained by a party determine its power in the coalition negotiations. The need to form a coalition to obtain a majority likely weakens the voter's influence on the eventual outcome. The reason is that given distributions of seats (power) among parties may allow multiple possible coalitions. As such, the second stage in the process of forming a political majority may be a black box to the voter, introducing uncertainty and lowering his influence on the outcome. The second factor in the instrumental benefit term in expression (1), $\left(U_{i}-U_{N}\right)$, gives the difference between the utility gained from party/coalition $\mathrm{i}$ and the party/coalition which is used as a reference point in the analysis, viz. party/coalition N. The larger this difference, the higher are the potential gains from 
casting a vote to the voter. Hence, the "instrumental" benefit for the voter in a multicandidate context "therefore is a series of terms in which each term represents a paired comparison" between party/coalition $\mathrm{N}$ and any other party/coalition (McKelvey and Ordeshook, 1972, 52).

- The costs of voting (C) comprise two different elements. Firstly, there are the costs one incurs by getting informed about the candidates and parties in the election. These are borne before Election Day and are relatively minor in size. Indeed, it is often argued that a lot of information is accessed without real effort by the potential voter through news broadcasts and/or overhearing discussions in public areas (Downs, 1957; Aldrich, 1993). Secondly, the voter suffers opportunity costs during the act of voting. The argument here is that while an individual is in (or on the way to or from) the polling station, (s)he cannot perform another activity.

- Downs' (1957) original model was restricted to the "instrumental" benefits of voting. This restriction led to the "paradox of voting". One single vote has practically no influence on the election outcome (whenever the electorate reaches a certain size) such that the "instrumental" benefits are close to zero. Given the existence of positive - though admittedly small - costs attached to this action, no individual would rationally vote for instrumental reasons. ${ }^{2}$ Still, in reality, significant turnout rates are observed even when voting is not compulsory (Geys, 2002). To overcome this paradox, several solutions have been proposed (for a review, see Dhillon and Peralta, 2002; Geys, 2005a). The most common is to include "expressive" or "consumption" benefits of voting (e.g. Riker and Ordeshook, 1968). These expressive benefits (D) entail the satisfaction from compliance with the ethics of voting ("civic duty"), from affirming allegiance to the political system 
or a political party, from deciding who to vote for and going to the polls ("entertainment value") and from the affirmation of one's efficacy in the political system (Riker and Ordeshook, 1968, 28).

One final remark is necessary. Expression (1) applies to all potential voters, irrespective of their favourite party. This can be seen most clearly if we regard the simpler case where two parties compete under plurality rule. Then, $\mathrm{N}=2$ and the possible "winners" are parties 1 and 2. Using party 2 as the point of reference in the analysis, the above expression reduces to:

$$
\mathrm{R}=\left(p_{1}^{V}-p_{1}^{A}\right)\left(U_{1}-U_{2}\right)-\mathrm{C}+\mathrm{D}>0
$$

Rewriting $\left(p_{1}^{V}-p_{1}^{A}\right)$ as $\mathrm{p}$ and $\left(U_{1}-U_{2}\right)$ as $\mathrm{B}$, we get:

$$
\mathrm{R}=p \mathrm{~B}-\mathrm{C}+\mathrm{D}>0
$$

This is the common formulation of the Calculus-of-Voting model by Riker and Ordeshook (1968) where $p$ is the probability that a voter is decisive in bringing about his favourite party's victory. For a voter favouring party 1 (2), the p-term as well as the B-term in the above expression will be positive (negative). 


\section{Literature Review}

\subsection{Theory}

The general intuition behind the concept of fragmentation may be clear: it refers to the number of parties that participate in the election. Still, many authors have used - often implicitly - definitions that are broader. This has sometimes led to confusion and ambiguous discussions of empirical results. Two dimensions can be distinguished: the number of parties and the size inequalities between them. Both these elements may have a (separate) effect on the voter's Cost-Benefit analysis, and thereby on turnout. In this section, we present theoretical arguments about the likely influence of the number of parties as well as their size inequalities.

\section{a) The number of parties}

There is no consensus in the vast literature on voter turnout whether - from a theoretical point of view - the number of parties in the election can be expected to increase or decrease turnout. Each point of view is supported by several arguments.

A positive effect can be expected on the basis of two arguments. Firstly, a larger number of parties enriches the choice offered to the electorate. This is likely to lower possible alienation feelings within the electorate by increasing the probability that voters can identify with some party (Seidle and Miller, 1976; Blais and Carty, 1990 and Hansen, 1994). This closer identification can be expected to enlarge the "expressive" benefits (D) of voting to the individual (Schuessler, 2000). Secondly, Dittrich and Johansen (1983) argue that the 
existence of more parties increases the competitiveness of the party system and thus the potential "instrumental" benefits (B) from selecting "good policy". However, this argument may be flawed as one could expect that in a more competitive system the quality of any proposed policy will be higher. Indeed, there is no guarantee that this general increase in the quality of policies proposed also increases the difference in utilities between policy platforms. And, following Downs (1957), the expected "instrumental" benefit of the voter depends on this difference rather than on the level of the preferred platform. A positive effect on turnout may, however, still be expected if "higher quality politics in general" allows the voter to identify himself more easily with a political platform (creating "expressive" benefits to casting a ballot).

A negative effect can be expected as an increase in the number of parties is likely to enlarge the need for coalition formation under given electoral rules (Jackman, 1987; Blais and Carty, 1990 and De Winter et al., 1991). As mentioned in section 1, this decreases the influence of the electorate in the choice of who governs it - formally it results in a lower or more uncertain value of $p$, the probability that an individual's vote will be decisive - and thus is likely to decrease its willingness to vote. Blais and Dobrzynska (1998) contend also that more parties might increase the complexity of the political system. This not only makes it harder for the voter to make up his mind, but also increases his (information) costs $(\mathrm{C})$ in general. Facing higher costs reduces the voter's likelihood of heading to the polls.

b) Size inequalities between the parties

Size inequalities between the parties are an important element of political fragmentation and constitute a potentially relevant influence on voter turnout. In fact, when discussing the 
empirical literature later on, it will become clear that many authors analysing the effect of size fragmentation on turnout implicitly take this influence into account. They do this via the use of concentration indices borrowed from industrial economics. Such indices, for instance the "effective" number of parties (ENP, Laakso and Taagepera, 1979), regard the effect of the number of participants as well as their relative sizes. Unfortunately, hitherto there is little formal theoretical argument given as to why size inequalities influence the level of voter turnout. We bring two reasons to the reader's attention: the expected closeness of the election and the incidence of dominant parties.

First of all, size inequalities may be an important measure for the expected closeness of the election. This closeness positively affects the probability for a single voter to be decisive $(p)$ and thus affects turnout. Actually, in two-party contests the expected equality - formally: the difference in expected vote shares between both candidates (or parties) - is the standard way to measure closeness. The general intuition there is clear. A marginal voter is more likely to be decisive if both parties have an expected vote share of $50 \%$ than if the expectations are such that one party has, say, an $85 \%$ expected vote share. However, a generalisation of this argument to situations where more than two parties compete under plurality rule or to alternative electoral rules is not straightforward.

Secondly, size inequalities between parties may be of relevance irrespective of the fact that they proxy closeness. Where the coalition formation process is not exogenous, the second stage of government formation is a "black box" to the voters. In such case, size inequalities may reflect power inequalities in the coalition negotiations and, importantly, in the government (cfr. Stigler, 1972). Large size inequalities could refer to the presence of powerful political parties that dominate politics. Obviously, this "dominance" could refer to 
either of two separate elements. Firstly, parties may become so big that they are expected to have a majority of the votes. In that case, the individual voter plays no role and might as well stay home (the probability $p$ of being decisive equals 0 ). Hence, dominance in this sense leads to lower turnout. Secondly, dominance may refer to playing a dominant role in coalition negotiations. The presence of a large party in such negotiations reduces the number of possible coalitions that can be formed (given the formation of majority coalitions). In fact, the number of majority coalitions that can be formed is at a maximum when the votes/seats are distributed perfectly equal and at a minimum when one party holds all the votes/seats. Increasing the level of inequality in the votes/seats distribution between these two extremes always leads to a non-increasing number of coalition possibilities. Hence, the formation process becomes "easier" (i.e. more transparent and predictable) when there is a large party and dominance can then be expected to increase turnout. In other words, the size inequalities may make the second stage in the process of forming a political majority less of a black box.

\subsection{Empirical literature}

The vast majority of the empirical work on voter turnout can be categorized in one of two types: individual-level and aggregate-level analyses. Whereas the former take the individual voter as the focus of the analysis, the latter regard turnout rates in municipalities, states or countries as the central element of analysis. However, the effect of fragmentation on turnout has been most often studied using aggregate data. The discussion of the empirical results of these analyses - with respect to fragmentation - is summarised in table 1 . The table is structured as follows. Of each study (mentioned in column 1), we first give the exact definition of the fragmentation variable(s) used and the sample studied in columns 2 and 3 respectively. Column 4 presents whether or not fragmentation has a turnout-increasing effect 
and the last column testifies of the statistical significance of the fragmentation effect. Each "Yes" indicates statistical significance at least at the 95 percent confidence level.

Table 1 about here

The studies in table 1 have been subdivided into three groups.

- Firstly, there are ten studies that use a fragmentation measure that only taps into the first dimension of fragmentation, the number of parties. Seidle and Miller (1976) and Settle and Abrams (1976) do so by introducing a dummy variable. They come to opposite conclusions. Seidle and Miller (1976) find that the competition of three candidates for one seat significantly increases turnout compared to a two-candidate contest in a crosssection of 144 UK counties (1964 and 1966). Analysing a time-series of 26 US presidential elections Settle and Abrams (1976) find that a third candidate significantly reduces turnout.

Six other studies in this category introduce the actual number of parties that contest the election as their measure of fragmentation (Crepaz, 1990; De Winter et al., 1991; Kaempfer and Lowenberg, 1993; Hoffman-Martinot, 1994; Hansen, 1994 and HoffmanMartinot et al., 1996). ${ }^{3}$ Once again, the conclusions contradict each other. Both studies on municipal elections in France find that a larger number of parties significantly reduces turnout (Hoffman-Martinot, 1994 and Hoffman-Martinot et al., 1996) while the opposite is true for municipal elections in Norway (Hansen, 1994). A possible explanation lies in the difference in the electoral rules used in both countries. France elects its municipal councillors via a two-ballot majority system, while Norway has a system of proportional 
representation. Whereas votes for smaller parties may easily be considered "wasted votes" in the French system, this is not so in the Norwegian system. Individuals who want to vote for small parties thus have less reason to turn out in France than in Norway. ${ }^{4}$ The same contradictive signs are found in cross-country studies. A positive effect is found in the analysis of 19 countries of Crepaz (1990), while Kaempfer and Lowenberg (1993) find a negative effect in their analysis of 59 countries. De Winter et al. (1991) show the effect of the number of parties to be non-linear when they regard all Belgian municipalities in the 1988 municipal elections. Turnout marginally increases with the number of parties until four parties and sharply decreases afterwards.

Finally, the last two studies in this category (Franklin and Hirczy, 1998 and Franklin, 1999) employ the number of years of "divided" government in the US as their measure of political fragmentation. Both papers find that turnout levels decrease significantly with the number of years of divided government.

- A second group of five studies employs a fragmentation variable that considers both the number of parties and the size inequalities between them. All five studies look at legislative parties rather than all parties that participated in the election. Jackman (1987) and Pérez-Linàn (2001) consider the "effective" number of parties. Jackman (1987) finds that turnout significantly decreases with the number of effective parties in the legislature of 19 industrial democracies. Pérez-Linàn (2001) estimates the same model using data on 17 Latin American countries. She finds an (insignificant) positive effect of fragmentation. Jackman and Miller (1995) use the inverse of the ENP-index as well as a related index presented by Molinar (1991). Both operationalizations provide a significant negative coefficient, indicating turnout to decline with the ("effective") number of parties. 
Kirchgässner and Schimmelpfennig (1992) and Kirchgässner and Zu Himmern (1997) analyse turnout in elections for the German Bundestag where a hybrid electoral system is used, combining elements of both plurality and PR. They focus on the effect of (expected) closeness. The latter is measured by the expected difference in votes between the two major candidates. As an alternative, and to capture effects from three or four party contests, they use an "entropy" measure $E=-\sum_{i=1}^{n} p_{i} \ln \left(p_{i}\right)$. This measure, in general, leads to more significant results. To our opinion, and as discussed above, this can be interpreted as evidence for the existence of a number-of-parties effect over and above the closeness effect that the authors concentrate on (and which, in our terminology is a sizeinequalities effect). Indeed, entropy, like the ENP or any other concentration index depends on both the size-inequalities between parties and the number of parties. ${ }^{5}$

- Finally, three studies explore both types of fragmentation variables; using the "actual" as well as the "effective" number of parties (Blais and Carty, 1990; Blais and Dobrzynska, 1998 and Blais, 2000). We must note, however, that the final regression equation in each study includes only the fragmentation variable that gave the best results (see table 1). All three studies analyse data on more than 300 elections and find that turnout is significantly depressed at higher levels of political fragmentation. Interestingly, Blais and Dobrzynska (1998) and Blais (2000) find that the number of parties best explains the observed variation in turnout, whereas Blais and Carty (1990) report a preferred regression result with the effective number of parties as the indicator of political fragmentation (thus referring to a separate effect from size inequalities).

\section{Empirical analysis}


The system of PR that underlies municipal politics in Flanders leads to a highly fragmented political landscape in most jurisdictions. We analyse how this fragmentation affects turnout. Our analysis explains turnout in the 2000 municipal elections for 307 of the 308 Flemish municipalities (all except Herstappe). It is important to note that Flemish municipalities have compulsory voting. Still, this compulsory character is to a large extent 'symbolic' as penalisation is virtually non-existent in practice. Figures about the level of prosecution for the municipal election year 2000 were obtained by surveying the 13 Flemish judicial areas. Non-voters were prosecuted in but 2 of these (Turnhout and Mechelen). And even here, only about 1 percent of the non-voters was prosecuted (391 individuals on a total of 34,260 nonvoters in these areas). ${ }^{6}$ Not only is the number of people that do not adhere to this law large, there is also significant inter-municipal variation in the turnout rates. It is this variation that we analyse in this paper.

As an introduction to the empirical work, in section 3.1 we provide some summary statistics and background information on turnout and political fragmentation in the Flemish municipalities. Section 3.2 presents the empirical model. Central attention is thereby given to the effect of political fragmentation. Section 3.3 contains a discussion of the main results.

\subsection{Turnout and political fragmentation in the Flemish municipalities}

The central variable for our empirical work is the percentage turnout in the municipality, defined as the number of votes cast (valid as well as invalid) divided by the number of registered voters. The variation in turnout rates among the 307 Flemish municipalities is 
depicted in figure 1. Turnout rates are given on the $\mathrm{X}$-axis, while the number of municipalities with a given level of turnout is read from the Y-axis. It can be seen that turnout is generally very high. In fact, the average turnout rate during the 2000 elections in the 307 municipalities considered in the analysis was $94,11 \%$. Still, it is clear that there is a reasonable amount of variation between the turnout rates of the Flemish municipalities - even though voting is (theoretically) compulsory. More precisely, turnout rates varied between $98.46 \%$ in Mesen and $87.95 \%$ in Drogenbos and displayed a standard deviation of $2.00 \%$.

Figure 1 about here

In table 2 we present some figures concerning political fragmentation levels in the 307 Flemish municipalities. It can be seen that in the average municipality about 5 political parties competed in the election. Although some of the lists that are presented to the voter are actually cartels of a number of parties or political groups, we refer to these lists as being a 'party' because they present one common alternative to the voter. There is also significant variation. That fragmentation at the election level also leads to fragmented parliaments (and governments) is clear from the fact that the average Flemish municipality has about 4 parties in the council and just under two parties forming a coalition. More detailed figures (not in the table) reveal that 96 municipalities had a single-party majority while 49 had a coalition of three or more parties.

Table 2 about here 


\subsection{Empirical model}

Our empirical model relates electoral turnout to indicators of political fragmentation while controlling for other "typical" determinants of voting behaviour. These controls where derived from a thorough reading of the relevant literature (Geys, 2005b) and lead us to estimate the following model using data on the municipal elections of 2000 for 307 Flemish municipalities:

$$
\mathrm{T}_{\mathrm{i}}=\gamma+\beta_{1} \mathrm{X}_{\mathrm{i}}+\beta_{2} \mathrm{FRAG}_{\mathrm{i}}+\varepsilon_{\mathrm{i}}
$$

where $i(=1$ to 307$)$ is an index for municipality $i$ and where $T_{i}$ is a logistic transformation of turnout $\left(\mathrm{T}_{\mathrm{i}}=\ln \left(\right.\right.$ Turnout $_{\mathrm{i}} /\left(1-\right.$ Turnout $\left.\left._{\mathrm{i}}\right)\right)$. Such a transformation is necessary as the range of turnout is limited to the 0 to 100 percent interval. If we would simply use a linear estimation method, the estimated turnout numbers are not constrained to lie within this interval. After transformation, the dependent variable ranges from negative infinity to positive infinity, eliminating predictions outside the allowable range (Thomas, 1997).

The $\mathrm{X}_{\mathrm{i}}$-vector is composed of the following eight control variables: number of registered voters (REG); population density (per $\mathrm{m}^{2}$; DENS); (out- and inward) migration as $\%$ of population (MIGR); population over 65 as $\%$ of population (AGE); unemployed as $\%$ of population (UNEM); per capita taxable income (in 1000 Euro; Y); income inequality (ratio of interquartile difference in income to the median value; INCDIV) and, finally, a dummy that equals 1 for municipalities in those judicial areas where non-voters are prosecuted ( 0 for all other municipalities; PROSEC). As mentioned before, there are only two judicial areas that prosecuted non-voters after the 2000 municipal elections: Turnhout and Mechelen. They 
cover 40 of the 307 municipalities in our population. ${ }^{7,8}$ Note that the obligation to vote implies that costs may also be incurred if one decides not to turn out (these costs could be either legal fines or social sanctions). So, technically speaking, these 'avoided costs of nonvoting' can be seen as benefits from voting.

These explanatory variables are determinants of $p, \mathrm{~B}, \mathrm{C}$ or $\mathrm{D}$ (cfr. section 1$)$. It should be clear, however, that classifying determinants may not always be unambiguous as some may affect more than a single variable in the theoretical model. We return to this issue while discussing our empirical results.

Finally, FRAG measures the effect of political fragmentation on voter turnout. This is where our model diverges significantly from the previous literature. Indeed, a vast majority of the studies to date have either used the "actual" or the "effective" number of parties to measure political fragmentation. However, when regarding the actual number of parties, one implicitly assumes that the size inequalities between the parties do not matter. To the extent that they do matter, this leads to misspecification and biased estimation results. If, on the other hand, one uses the "effective" number of parties, one imposes that both elements of fragmentation affect turnout. When this (implicit) assumption is not met by the data, this leads to a reduction in the efficiency of the model's parameter estimates. More importantly, combining the number of parties and size inequalities in one index precludes the analysis of both elements' separate effects on voter turnout. ${ }^{9}$

Both these issues can be resolved by separating the "effective" number of parties into two distinct measures for the number of parties and size inequalities respectively. This idea is taken from Davies (1979) who argued - in the context of industry concentration - that such a separation is possible for any concentration index. Specifically, following Davies (1980), 
Davies et al. (1988) and Chakravarty (1995), the "effective" number of parties can be written as:

$$
\mathrm{ENP}=\frac{\mathrm{NoP}}{1+\mathrm{cv}^{2}}
$$

with cv $=\frac{\sqrt{\frac{1}{N o P} \sum_{i=1}^{N o P}\left(s_{i}-\bar{s}\right)^{2}}}{\bar{s}}$

where $\mathrm{s}_{\mathrm{i}}$ represents the share of votes for party $\mathrm{i}$ in the election, $\bar{s}$ is the average vote share over all parties and NoP equals the number of parties in the election. The coefficient of variation (cv) is a well-known and "popular index of inequality" (Chakravarty, 1995, 20). Importantly, by including NoP as well as $I\left(=1+\mathrm{cv}^{2}\right)$ in the empirical analysis, it is possible to assess the size, significance and direction of the effects of both elements of fragmentation separately.

\subsection{Empirical results}

Table 3 presents the results of our estimation. Prior to discussing our findings with respect to the independent variables, we first draw attention to the functional form of the specification. Columns (1) and (2) in table 3 present the results of a linear model. ${ }^{10}$ Columns (3) and (4) show the findings of a loglinear specification (where we take the natural logarithm of all explanatory variables). We perform Ramsey's (1969) Regression Equation Specification Error Test (RESET). This test involves adding powers of the fitted values of the original model into the equation (squared for $\mathrm{RESET}^{2}$ and squared and cubed for RESET ${ }^{3}$ ) and Ftesting the statistical significance of these "variables". If there is no misspecification (of the functional form), these should not have any explanatory value. The results - presented at the bottom of table 3 - indicate that the test statistics for RESET ${ }^{2}$ as well as $\mathrm{RESET}^{3}$ are statistically significant at least at the $10 \%$ level in a linear specification, but not in a loglinear 
specification. As a consequence, further interpretations will centre on the loglinear specification.

Table 3 about here

Table 3 shows that the overall fit of the model is very good. Almost $60 \%$ of the variation in turnout between the Flemish municipalities can be explained by the variables in our model. The number of parties negatively affects electoral turnout. Hence, the possible positive effects associated with multi-party systems (through lower alienation and a more competitive political system) seem to be dominated by the negative effects (higher need for coalition formation and higher informational costs). De Winter et al. (1991) observed a similar negative effect in the 1988 municipal elections in Flanders (and in Belgium as a whole).

The coefficient for size-inequalities in table 3 shows that electoral turnout is higher the more unequal in size are the political parties. A possible explanation for this positive sign is that the presence of parties that dominate the political landscape increase the representative voter's incentives to turn out. We have already indicated at the outset of the present paper that this is most likely due to the increased transparency and predictability of the coalition formation process. This may strengthen the (perceived) link between the individual voter's vote and the political outcome of the elections - thus leading to an increased voter turnout. However, the parameter estimate for the effect of size inequalities only approaches statistical significance at the $10 \%$ level $(\mathrm{p}=0.13)$. Hence, the additional effect of size inequalities is statistically rather weak. ${ }^{11}$ 
Having discussed the fragmentation variables, we now turn to a discussion of the other variables included in the model. As mentioned earlier, these variables are determinants of $p$, $\mathrm{B}, \mathrm{C}$ and/or D (section 1), though it is clear that their classification under only one of these headings is not always unambiguous (see below). From table 3 we see that all but two of the control variables included in the model have a significant effect on electoral turnout in Flanders. First, the number of registered voters (REG) significantly reduces turnout. This is in line with the Downsian argument that a larger voting population decreases the probability (p) that one vote will make a difference (Downs, 1957). Secondly, higher migration levels (MIGR) depress turnout. This may suggest that municipalities with a highly stable population have a tighter social network and community life with higher "social pressure" (Karnig and Walter, 1974 and Hoffman-Martinot, 1994). Also, Hoffman-Martinot (1994) argues that stable, self-centred communities might grow stronger feelings of identification, also increasing social pressure to turn out the vote. Both elements increase the value of the Dterm. An alternative explanation for the negative migration-effect may be that voters who have resided in the same community for a longer period are more aware of local issues and candidates (Filer et al., 1993). This implies that they face lower information costs (C). Finally, higher (out)-migration may indicate that people do not vote as, actually, they might live elsewhere in the near future and will thus be unaffected by local policy (B).

Population density (DENS) is negatively correlated with turnout. This may indicate that residents of more densely populated areas are less well integrated in the community as urbanisation leads to "a weakening of interpersonal bonds" (Hoffman-Martinot, 1994, 14; see also Wirth, 1938). As a consequence, the social pressure to vote will be weaker, depressing the D-term and thereby turnout. The coefficient on the dummy variable for the municipalities in judicial areas where non-voters were prosecuted (PROSEC) - relating to the costs $(\mathrm{C})$ that 
people may avoid by voting - shows a significant negative sign. This is somewhat counterintuitive: it indicates that the municipalities in jurisdictions where non-voting is in practice penalised are actually confronted with lower turnout. Two explanations are possible: the higher prosecution level reflects the response to a "structural" lower turnout level or higher prosecution levels crowd-out the intrinsic motivation of the Flemish voter to participate in the electoral process (Frey, 1997). ${ }^{12}$ The latter argument refers to the possibility that feelings of civic duty (D) among the population are diluted by a government that - by prosecuting - reveals a lack of trust in its citizens.

While a larger proportion of elderly in the population (AGE) also tends to depress turnout at the polls, unemployment (UNEM) and average income (Y) do not reach generally accepted levels of significance. ${ }^{13}$ Finally, income diversity (INCDIV) has a significantly negative effect on turnout. As a measure for the socio-economic heterogeneity of the population, income diversity may weaken social pressure within the community to turn out to vote. It has been argued that "planners who are concerned with building communities (...) have accepted the fact that social homogeneity is a necessary prerequisite of community cohesion" (Cohen, 1982, 259). More cohesion can be expected to increase group solidarity (Ashworth et al., 2002) and thus social pressure towards electoral turnout (D). 


\section{Conclusion}

Using data on the 2000 municipal elections in Flanders we show that the number of parties in the election has a negative impact on turnout. Possible positive effects of multi-party systems on turnout (through lower alienation and a more competitive political system) are dominated by negative effects (higher need for coalition formation and higher informational costs). This contradicts the results in Hansen (1994) where a positive effect of the number of parties on turnout was found in a context with proportional representation. A possible explanation for this remarkable difference may be the fact that Flemish municipalities - unlike their Norwegian counterparts - have a parliamentary system. In Norwegian municipalities executive boards are established in which all parties have members according to their share of seats in the council (Tovmo, 2001). Our result may be taken to suggest that in Flemish municipalities the increased probability for coalition formation in municipalities with more parties actually discourages the electorate because its direct influence in choosing their government decreases. The estimated effect from the size inequalities between the parties is positive. Turnout thus appears to be higher the more unequal in size are the political parties. However, this effect is not statistically significant at conventional levels of significance. The size inequalities between the parties thus do not significantly add to the explanatory power of the model (once the number of parties is taken into account).

These results support the finding in the literature that political fragmentation is an important determinant of electoral turnout. The central contribution of the present paper, however, was to present a method that allows disentangling the effects of two dimensions of fragmentation: the number of parties that participate in the election and the size inequalities between those parties. Thus far, in the literature either one of these dimensions was ignored (looking only at 
the number of parties) or they were lumped into one index. Separation of the effects of both fragmentation dimensions is important for both statistical and empirical reasons. From a statistical point of view, it is important to avoid misspecification or lack of efficiency of the model. From an empirical point of view, only by disentangling the effects it is possible to assess the impact of both the number of parties and the size inequalities. For both these impacts several theoretical arguments have been presented. Disentangling the fragmentation index is indispensable to test these. 


\section{References}

Ackaert, J., L. De Winter, A.-M. Aish and A.-P. Frognier, 1992. L'abstentionnisme électoral et vote blanc et nul en Belgique, Res Publica, 34 (2), 209-226.

Aldrich, J., 1993. Rational Choice and Turnout, American Journal of Political Science, 37 (1), 246-278.

Ashworth, J., B. Heyndels and C. Smolders, 2002. Redistribution as a Local Public Good: an Empirical Test for Flemish Municipalities, Kyklos, 55 (1), 27-56.

Blais, A., 2000. To Vote or not to Vote? The Merits and Limits of Rational Choice Theory, University of Pittsburgh, Pittsburgh.

Blais, A. and R.K. Carty, 1990. Does Proportional Representation foster Voter Turnout, European Journal of Political Research, 18, 167-181.

Blais, A. and A. Dobrzynska, 1998. Turnout in Electoral Democracies, European Journal of Political Research, 33, 239-261.

Chakravarty, S.R., 1995, Issues in Industrial Economics, Avebury, Aldershot.

Cohen, G., 1982. Community Cohesion and Space Planning, in: R. Frankenberg (ed.), Custom and Conflict in British Society, Manchester University Press.

Crepaz, M.M.L., 1990. The Impact of Voter Polarisation and Postmaterialism on Voter Turnout, European Journal of Political Research, 18, 183-205.

Davies, S., 1979. Choosing between Concentration Indices: the Iso-Concentration Curve, Economica, 46, 67-75.

Davies, S., 1980. Measuring Industrial Concentration: an Alternative Approach, Review of Economics and Statistics, 62 (2), 306-309.

Davies, S., B. Lyons, H. Dixon and P. Geroski, 1988. Economics of Industrial Organisation, London: Longman.

De Winter, L., J. Ackaert, A.-M. Aish and A.-P. Frognier, 1991. L'abstentionnisme électoral et le vote blanc ou nul en Belgique, Université Catholique de Louvain.

Dhillon, A. and S. Peralta, 2002. Economic Theories of Voter Turnout, The Economic Journal, 112, F332-F352.

Dittrich, M. and L.N. Johansen, 1983. Voting Turnout in Europe, 1945-1978: Myths and Realities, pp. 95-114, in: H. Daalder and P. Mair (eds.), Western European Party Systems, London: Sage Publications.

Downs, A., 1957. An Economic Theory of Democracy, New York: Harper and Row.

Duverger, M., 1972. Political Parties: Their Organisation and Activity in the Modern State, London: Methuen.

Filer, J.E., 1977. An Economic Theory of Voter Turnout, Dissertation, UMI Dissertation Services, Michigan: Ann Arbor.

Filer, J.E., L.W. Kenny and R.B. Morton, 1993. Redistribution, Income and Voting, American Journal of Political Science, 37 (1), 63-87. 
Franklin, M.N., 1999. Electoral Engineering and Cross-National Turnout Differences: What Role for Compulsory Voting?, British Journal of Political Science, 29, 205-224.

Franklin, M.N. and W.P. Hirczy de Mino, 1998. Separated Powers, Divided Government and Turnout in US Presidential Elections, American Journal of Political Science, 42 (1), 316-326.

Frey, B.S., 1997. Not Just for the Money: An Economic Theory of Personal Motivation, Chelmont: Edward Elgar Publishing.

Geys, B., 2002. Economische rationaliteit en opkomst bij verkiezingen, Nieuw Tijdschrift van de Vrije Universiteit Brussel, 15 (1), 20-34.

Geys B., 2005a, 'Rational' Theories of Voter Turnout: a Review, Political Studies Review, forthcoming.

Geys, B., 2005b. Explaining Voter Turnout: a Review of Aggregate-Level Research, Electoral Studies, forthcoming.

Hannah, L. and J.A. Kay, 1977. Concentration Measures in Modern Industry: Theory, Measurement and UK Experience, London: MacMillan Press.

Hansen, T., 1994. Local Elections and Local Government Performance, Scandinavian Political Studies, 17 (1), 1-30.

Hoffman-Martinot, V., 1994. Voter Turnout in French Municipal Elections, pp. 13-42, in: L. Lopez-Nieto (ed.), Local Elections in Europe, Barcelona: Institut de ciènces politiques I socials.

Hoffman-Martinot, V., C. Rallings and M. Thrasher, 1996. Comparing Local Electoral Turnout in Great-Britain and France: More Similarities than Differences?, European Journal of Political Research, 30, 241-257.

Jackman, R.W., 1987. Political Institutions and Voter Turnout in the Industrial Democracies, American Political Science Review, 81 (2), 405-423.

Jackman, R.W. and R.A. Miller, 1995. Voter Turnout in the Industrial Democracies during the 1980s, Comparative Political Studies, 27 (4), 467-492.

Karnig, A.K. and O.B. Walter, 1974. Electoral Turnout in Municipal Elections: A Multivariate Analysis, The Rocky Mountain Social Science Journal, 11 (2), 55-71.

Kaempfer, W.H. and A.D. Lowenberg, 1993. A Threshold Model of Electoral Policy and Voter Turnout, Rationality and Society, 5 (1), 107-126.

Kirchgässner, G. and J. Schimmelpfennig, 1992. Closeness Counts if it Matters for Electoral Victory: Some Empirical Results for the United Kingdom and the Federal Republic of Germany, Public Choice, 73, 283-299.

Kirchgässner, G. and A-M Zu Himmern, 1997. Expected Closeness and Turnout: an Empirical Analysis for the German General Elections, 1983-1994, Public Choice, 91, 325.

Kramer, G.H., 1983. The Ecological Fallacy Revisited: Aggregate versus Individual-level Findings on Economics and Elections, and Sociotropic Voting, American Political Science Review, 77 (1-2), 92-111.

Laakso, M. and R. Taagepera, 1979. "Effective" Number of Parties: A Measure with Application to West Europe, Comparative Political Studies, 12 (1), 3-27. 
Lijphart, A., 1994. Electoral Systems and Party Systems: A Study of 27 Democracies, 19451990, Oxford: University Press.

Mc Kelvey R.D. and P.C. Ordeshook (1972), A General Theory of the Calculus of Voting, in J. F. Herndon and J. L. Bernd (eds.), Mathematical Applications in Political Science VI, University Press of Virginia, Charlottesville, 32-78.

Molinar, J., 1991. Counting the number of parties: An alternative index, American Political Science Review, 85 (4), 1383-1391.

Pérez-Linàn, A., 2001. Neo-Institutional Accounts of Voter Turnout: moving beyond Industrial Democracies, Electoral Studies, 20, 281-297.

Ramsey, J.B., 1969, Tests for Specification Error in Classical Least Squares Regression Analysis, Journal of the Royal Statistical Society, B31, 250-271.

Riker, W.H. and P.C. Ordeshook, 1968. A Theory of the Calculus of Voting, American Political Science Review, 62, 25-42.

Robinson, W.S., 1950, Ecological Correlation and the Behavior of Individuals, American Sociological Review, 15, 351-357.

Schuessler A.A., 2000, A Logic of Expressive Choice, Princeton University Press, Princeton.

Seidle, L. and D. Miller, 1976. Turnout, Rational Abstention and Campaign Effort, Public Choice, 27, 121-126.

Settle, R.F. and B.A. Abrams, 1976. The Determinants of Voter Participation: A More General Model, Public Choice, 27, 81-89.

Stigler, G.J., 1972. Economic Competition and Political Competition, Public Choice, 13, 91106.

Taagepera, R. and M.S. Shugart, 1989. Seats and Votes: The Effects and Determinants of Electoral Systems, Yale: University Press.

Thomas, R.L., 1997. Modern Econometrics: An Introduction, Harlow UK: Addison-WesleyLongman Ltd.

Tovmo, P., 2001, Budgetary Procedures and Deficits in Norwegian Local Governments, Norwegian University of Science and Technology, Trondheim, mimeo.

Vanmaercke, L., 1993. De stemplicht in vraag gesteld, Nieuw Tijdschrift voor Politiek, 9, 6378.

Wirth, L. (1938), Urbanism as a Way of Life, American Journal of Sociology, 44, 3-24. 
Table 1: Turnout studies incorporating political fragmentation

\begin{tabular}{|c|c|c|c|c|}
\hline $\begin{array}{l}\text { Study } \\
\end{array}$ & "Measure & Sample & Sign & "Significance \\
\hline \multicolumn{5}{|l|}{ "One dimension } \\
\hline $\begin{array}{l}\text { Seidle and Miller } \\
\text { (1976) }\end{array}$ & $\begin{array}{l}\text { Dummy equal to } 1 \text { in } 2- \\
\text { candidate contest and } 0 \text { in 3- } \\
\text { candidate contest }\end{array}$ & $\begin{array}{l}\text { U.K. county } \\
\text { seats in general } \\
\text { elections }\end{array}$ & Increase & Yes \\
\hline $\begin{array}{l}\text { Settle and Abrams } \\
\text { (1976) }\end{array}$ & $\begin{array}{l}\text { Dummy equal to } 0 \text { in } 2- \\
\text { candidate contest and } 1 \text { in } 3- \\
\text { candidate contest }\end{array}$ & U.S. presidential & Decrease & Yes \\
\hline Crepaz (1990) & NoP in legislature ${ }^{\mathrm{a}}$ & 16 countries & Increase & No \\
\hline $\begin{array}{l}\text { De Winter et al. } \\
\text { (1991) }\end{array}$ & $\begin{array}{l}\begin{array}{l}\text { Number of party lists in } \\
\text { election }\end{array} \\
\end{array}$ & $\begin{array}{l}\text { Belgian } \\
\text { municipalities }\end{array}$ & $\begin{array}{l}\text { Non- } \\
\text { linear }\end{array}$ & Yes \\
\hline $\begin{array}{l}\text { Kaempfer and } \\
\text { Lowenberg (1993) }\end{array}$ & $\begin{array}{l}\text { Number of "major" parties in } \\
\text { election }\end{array}$ & 59 countries & Decrease & No \\
\hline $\begin{array}{l}\text { Hoffman-Martinot } \\
\text { (1994) }\end{array}$ & NoP in election & $\begin{array}{l}\text { French } \\
\text { municipalities }\end{array}$ & Decrease & Yes \\
\hline Hansen (1994) & NoP in election & $\begin{array}{l}\text { Norwegian } \\
\text { municipalities }\end{array}$ & Increase & Yes \\
\hline $\begin{array}{l}\text { Hoffman-Martinot } \\
\text { et al. (1996) }\end{array}$ & NoP in election & $\begin{array}{l}\text { French } \\
\text { municipalities }\end{array}$ & Decrease & Yes \\
\hline $\begin{array}{l}\text { Franklin and } \\
\text { Hirczy (1998) }\end{array}$ & $\begin{array}{l}\text { Number of years of } \\
\text { "divided" government }\end{array}$ & $\begin{array}{l}39 \text { presidential } \\
\text { elections (US) }\end{array}$ & Decrease & Yes \\
\hline Franklin (1999) & $\begin{array}{l}\text { Number of years of } \\
\text { "divided" government }\end{array}$ & $\begin{array}{l}39 \text { presidential } \\
\text { elections (US) }\end{array}$ & Decrease & Yes \\
\hline \multicolumn{5}{|l|}{ Both dimensions } \\
\hline Jackman (1987) & ENP in legislature & 19 countries & Decrease & Yes \\
\hline $\begin{array}{l}\text { Kirchgässner and } \\
\text { Schimmelpfennig } \\
\text { (1992) }\end{array}$ & Entropy measure & $\begin{array}{l}\text { German and UK } \\
\text { General } \\
\text { Elections } \\
\end{array}$ & Increase & Yes \\
\hline $\begin{array}{l}\text { Jackman and } \\
\text { Miller (1995) }\end{array}$ & $\begin{array}{l}\text { ENP in legislature } \\
\text { Molinar-index }\end{array}$ & $\begin{array}{l}22 \text { democratic } \\
\text { countries }\end{array}$ & $\begin{array}{l}\text { Decrease } \\
\text { Decrease }\end{array}$ & $\begin{array}{l}\text { Yes } \\
\mathrm{No}^{c}\end{array}$ \\
\hline $\begin{array}{l}\text { Kirchgässner and } \\
\text { Zu Himmern } \\
\text { (1997) }\end{array}$ & Entropy measure & $\begin{array}{l}\text { German } \\
\text { Bundestag }\end{array}$ & Increase & Yes \\
\hline Pérez-Linàn (2001) & ENP in legislature & 17 countries & Increase & No \\
\hline \multicolumn{5}{|l|}{ Several indices $^{\mathrm{d}}$} \\
\hline $\begin{array}{l}\text { Blais and Carty } \\
\text { (1990) }\end{array}$ & $\begin{array}{l}\text { ENP in legislature } \\
\text { ENP in election } \\
\text { NoP in election } \\
\text { NoP in legislature }\end{array}$ & 20 countries & $\begin{array}{l}\text { Decrease } \\
- \\
- \\
- \\
\end{array}$ & $\begin{array}{l}\text { Yes } \\
- \\
- \\
- \\
\end{array}$ \\
\hline $\begin{array}{l}\text { Blais and } \\
\text { Dobrzynska (1998) }\end{array}$ & $\begin{array}{l}\text { NoP in election } \\
\text { ENP in legislature } \\
\text { ENP in election }\end{array}$ & $\begin{array}{l}91 \text { democratic } \\
\text { countries }\end{array}$ & $\begin{array}{l}\text { Decrease } \\
- \\
- \\
\end{array}$ & $\begin{array}{l}\text { Yes } \\
- \\
- \\
\end{array}$ \\
\hline Blais (2000) & $\begin{array}{l}\text { NoP in election } \\
\text { ENP in legislature } \\
\text { ENP in election }\end{array}$ & $\begin{array}{l}91 \text { democratic } \\
\text { countries }\end{array}$ & $\begin{array}{l}\text { Decrease } \\
- \\
- \\
\end{array}$ & $\begin{array}{l}\text { Yes } \\
- \\
- \\
\end{array}$ \\
\hline
\end{tabular}

Notes: ${ }^{a}$ NoP stand for the actual number of parties, ENP stands for the "effective" number of parties.

${ }^{\mathrm{b}}$ The number of lists has a slight positive effect up to 4 lists and affects turnout negatively afterwards.

${ }^{c}$ The variable is significant at the $10 \%$-level.

${ }^{\mathrm{d}}$ All measures were tried, but only one was reported. 
Table 2 : Descriptive statistics on Fragmentation (307 Flemish municipalities)

\begin{tabular}{||l|c|c||}
\hline \hline Number of parties in & \multicolumn{2}{|c|}{2000} \\
\hline & Average & Variance \\
\hline \hline Election & 5.17 & 3.01 \\
\hline Council & 4.29 & 1.82 \\
\hline Coalition & 1.87 & 0.52 \\
\hline
\end{tabular}

Source: Own calculations 


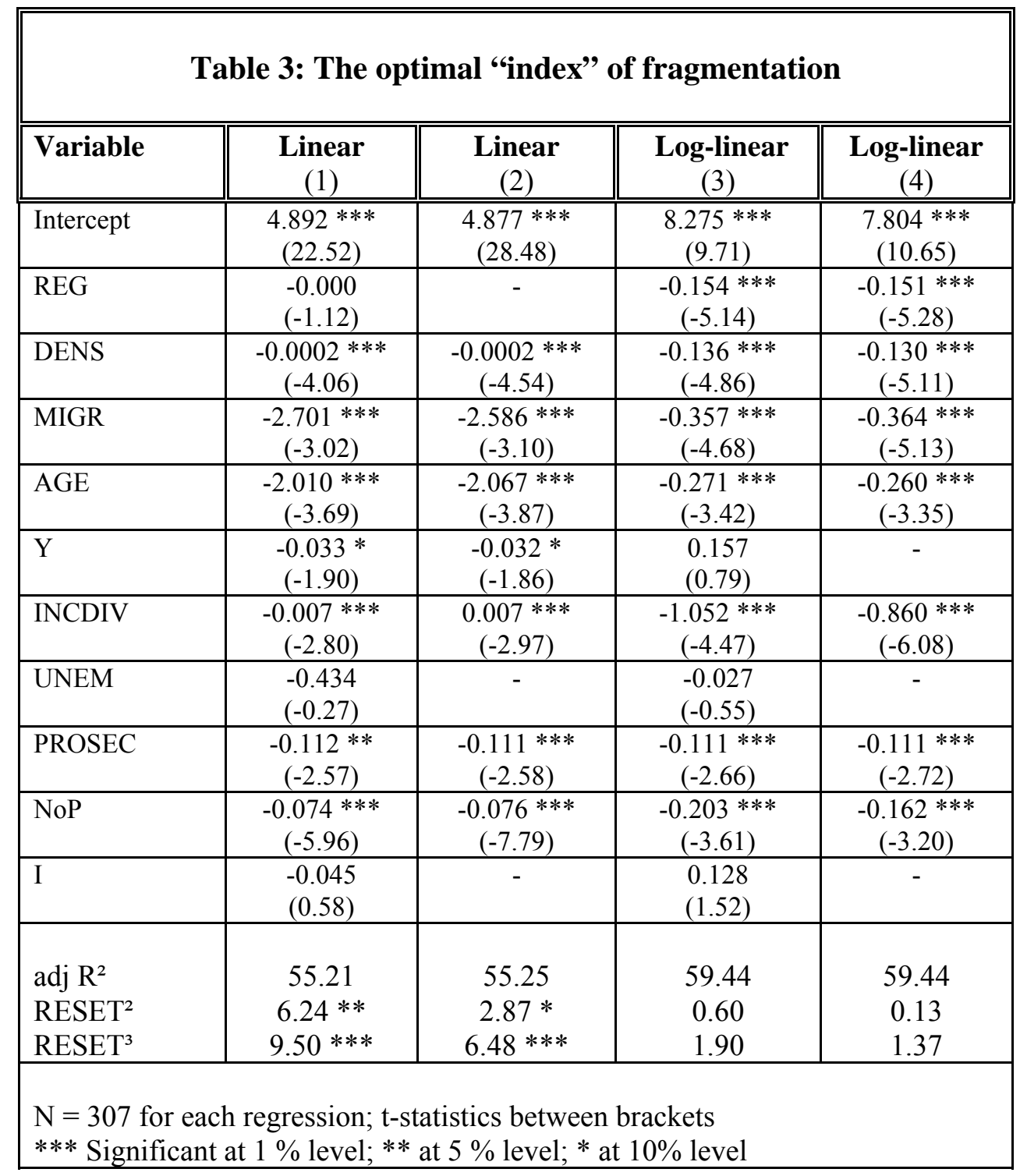


Figure 1: Distribution of municipal turnout rates for 307 Flemish municipalities

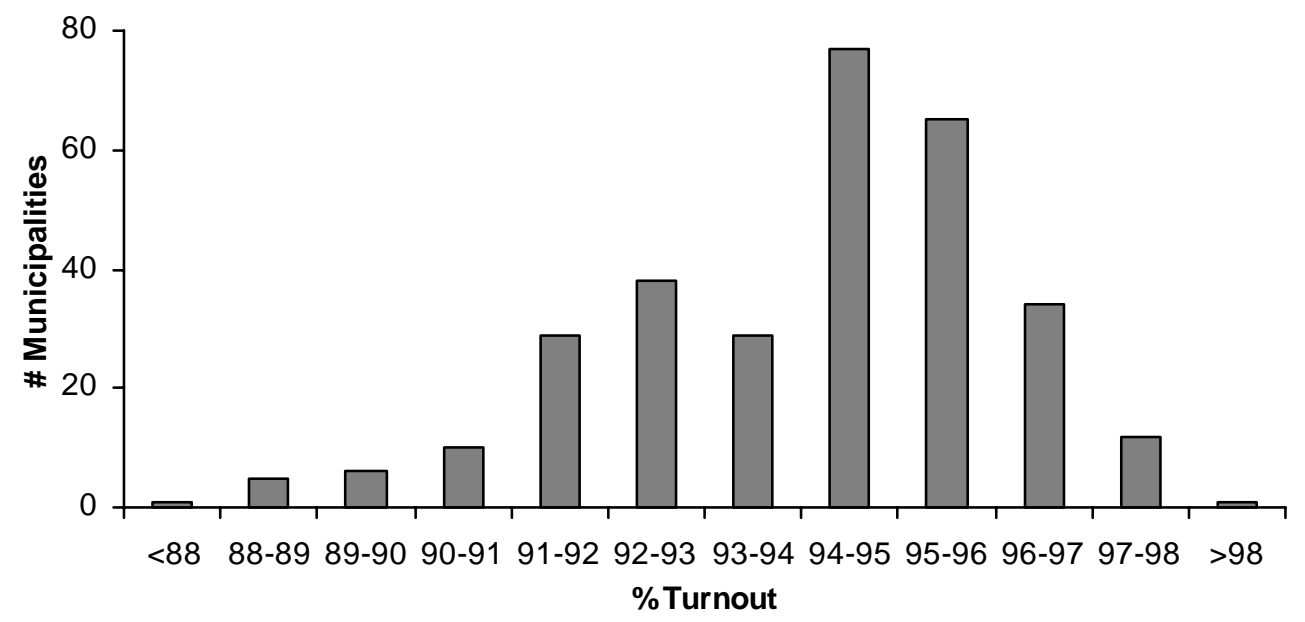

Source: Own calculations 


\section{Notes:}

1 Given the disproportionality of most electoral systems, this need not be a majority of the votes.

2 Stigler (1972, 102-104) and Filer (1977, 14-15), however, argue that the probability of casting a vote that determines the "winner" in the election is not the only relevant one. Voters may also turn out to increase the vote percentage for their party as higher support turns a political party more influential (even as opposition party). Still, they agree that the effect of any single vote(r) remains marginal in most situations such that "this restatement does not in turn magically dispose of the paradox" (Stigler, 1972, 104).

3 Crepaz (1990) uses the number of parties in the legislation and Kaempfer and Lowenberg (1993) use the number of "major" political parties in the election.

4 The reason why potential supporters of smaller parties may feel they waste their vote in non-proportional systems (a "psychological effect") is that small parties face a much higher hurdle to obtain representation in such systems (a "mechanical effect") (see Duverger, 1972). This higher threshold is likely to discourage voters of the smaller parties in the election.

5 We find it hard, however, to grasp the intuition of a closeness definition that considers a three-party-contest with expected votes $(0.48 ; 0.48 ; 0.04)$ much closer than a two-party contest with $(0.50 ; 0.50)$ expected votes (as indeed the entropy measure takes the value 0.83 and 0.69 respectively).

${ }_{6}$ Vanmaercke $(1993,66)$ reports even lower prosecution levels for the 1985 parliamentary elections. He shows that after these elections only 62 out of over 400,000 non-voters were fined in Belgium as a whole.

7 Using data on prosecution after the 2000 municipal election to explain turnout in that same election is not ideal. It (implicitly) assumes that the electorate can perfectly foresee whether or not prosecution will take place. Casual observation of the limited data that are available on prosecution of non-voters in earlier elections, however, show prosecution only in the same two judicial areas after the 1994 municipal elections.

8 Data on prosecution in the judicial area of Dendermonde are missing. We assume that this implies that no prosecution took place in the 32 municipalities in this area. Re-estimating our model dropping these municipalities has no significant effect on the estimated coefficients (results available upon request).

9 Using the "effective" number of parties (ENP) furthermore introduces a restriction into the model as one assumes a very specific relation between the number of parties and size inequalities. ENP corresponds to the inverse of the Herfindahl index. The latter gives the sum of squared vote shares over all parties. Still, there is no theoretical argument as to why the shares should be squared. The latter corresponds to using the more 
general Hannah and Kay (1977) concentration index, $\left(\sum_{i=1}^{n} \operatorname{Vote}_{i}^{\alpha}\right)^{(1 /(1-\alpha))}$, and setting $\alpha$ equal to 2 . Testing this restriction shows that there is no significant difference between the results using the optimal (adjusted $\mathrm{R}^{2}$ maximizing) $\alpha$ (equal to 0.9 ) and $\alpha=2$. Hence, we follow the main strand of the literature in focusing on the "effective" number of parties.

10 It should be observed that the linear specification does not take into account the non-linear decomposition of ENP discussed in section 3.2. We do, however, present the linear specification as a point of reference.

11 Including $\log \mathrm{NoP}$ and $\log \left(1+\mathrm{cv}^{2}\right)$ is only perfectly equivalent to including $\log (\mathrm{ENP})$ if we restrict the sum of the coefficients of both these variables to be equal to that of $\log (\mathrm{ENP})$. The results presented in Columns (3) and (4) of table 3 are obtained without imposing this restriction (creating a more general model to the one in which the restriction is imposed). Still, an F-test shows that we cannot reject that the restriction holds $\left(\mathrm{F}_{1}\right.$, $\left.{ }_{296}=2.02 ; \mathrm{p}>0.1\right)$. Moreover, imposing the restriction does not change the main tenor of the results (available upon request).

12 A simultaneous estimation technique and/or a panel analysis that takes into account variation of turnout over time is needed to discriminate between the different explanations. Unfortunately, data on prosecution of non-voting are not available for longer time periods.

13 In interpreting the parameter estimates of these three variables, one should be aware of the so-called "ecological fallacy". This refers to the bias that may occur because an association observed between variables at an aggregate level does not necessarily represent an association that exists at an individual level (see e.g. Robinson, 1950; Kramer, 1983). 